MURHUM : Jurnal Pendidikan Anak Usia Dini

E-ISSN: 2723-6390, hal. 48-57

Vol. 2 No. 2 Desember 2021

DOI : $10.37985 /$ murhum.v2i2.20

\title{
Metode Storytelling Melalui Musik Instrumental dalam Menstimulus Kemandirian Anak Usia Dini
}

\author{
Hilda Hidayati1, Yuyun Yulianingsih ${ }^{2}$, Teti Ratnasih ${ }^{3}$ \\ Jurusan Pendidikan Islam Anak Usia Dini, UIN Sunan Gunung Djati Bandung \\ e-mail : hildahidayati05@gmail.com
}

\begin{abstract}
ABSTRAK. Tujuan penelitaian ini adalah untuk mengetahui 1) Kemandirian anak di kelompok B Kober Alhuda Alal Kasbi sebelum diterapkan metode storytelling melalui musik instrumental. 2) Proses pembelajaran dan penerapan metode storytelling melalui musik instrumental di kelompok B Kober Alhuda Alal Kasbi pada seluruh siklus. 3) Kemandirian anak di kelompok B Kober Alhuda Alal Kasbi sesudah diterapkan metode storytelling melalui musik isntrumental pada seluruh siklus. Penelitaian ini menggunakan metode penelitian tindakan kelas. Alat pengumpulan data dalam penelitian ini berupa observasi, wawancara, dokumentasi dan unjuk kerja. Teknik analisis data yang digunakan adalah teknik analisis data kualitatif dan analisis data kuantitatif. Subjek/responden dalam penelitian ini adalah siswa/i Kober Al-Huda Alal Kasbi Cipacing yang berjumlah 13 orang pada tahun ajaran 2019/2020. Berdasarkan hasil analisis data diketahui bahwa kemandirian anak sebelum dilakukan tindakan memperoleh nilai rata-rata 51,35\% dengan kriteria kurang. Proses penerapan metode storytelling melalui musik instrumental dilihat dari aktivitas guru dan anak, pada siklus I observasi aktivitas guru mencapai 80,55\% dengan kriteria baik dan pada siklus II meningkat menjadi 94,44\% dengan kriteria sangat baik. Demikian pula dengan observasi aktivitas anak siklus I mencapai 68,8 dengan kriteria baik. Pada siklus II meningkat menjadi 79,69 dengan kriteria baik. Adapun kemandirian anak pada siklus I memperoleh rata-rata 57,88 dengan kriteria kurang. Pada siklus II kemandirian anak meningkat menjadi 86,53 dengan kriteria sangat baik.
\end{abstract}

Kata Kunci : Metode Storytelling; Musik Instrumental; Kemandirian

ABSTRACT. The purpose of this research was to determine 1) The independence of children in group B Kober Alhuda Alal Kasbi before applying the storytelling method through instrumental music. 2) The learning process and the application of the storytelling method through instrumental music in group B Kober Alhuda Alal Kasbi throughout the cycle. 3) The independence of the children in group B Kober Alhuda Alal Kasbi after applying the storytelling method through instrumental music in the entire cycle. This research uses classroom action research methods. Data collection tools in this study were observation, interviews, documentation and performance. The data analysis technique used is qualitative data analysis techniques and quantitative data analysis. Subjects / respondents in this study were 13 students of Kober Al-Huda Alal Kasbi Cipacing through instrumental music is seen from the activities of teachers and children, in the first cycle the observation of teacher activity reached $80.55 \%$ with good criteria and in the second cycle it increased to $94.44 \%$ with very good criteria. Likewise, the observation of children's activity in cycle I reached 68.8 with good criteria. In the second cycle it increased to 79.69 with good criteria. As for the independence of children in the first cycle obtained an average of 57.88 with less criteria. In cycle II, the child's independence increased to 86.53 with very good criteria.

Keyword : Storytelling Method;, Instrumental Musi;, Independence 


\section{PENDAHULUAN}

Perkembangan pendidikan di Indonesia dari masa ke masa terus mengalami kemajuan hal ini ditandai dengan adanya sistem serta peraturan pendidikan yang terus dikaji dan diperbaharui. Hal tersebut merupakan upaya pemerintah dalam memaksimalkan dan mengoptimalkan kualitas pendidikan di Indonesia agar menjadi lebih baik lagi serta menyiapkan peserta didik yang mampu bersaing baik di dalam maupun luar negeri. Dewasa ini pendidikan pra sekolah atau pendidikan anak usia dini sedang gencar di gaungkan di Indonesia. Mengingat dahulu masih banyak orang yang kurang mengetahui pentingnya pendidikan anak usia dini, mereka menganggap bahwa di PAUD itu hanya bermain saja dan tidak belajar serius. Tetapi, seiring berjalannya waktu dengan didukung oleh perkembangan ilmu pengetahuan dan teknologi yang semakin canggih, maka dalam mengakses informasi pun semakin mudah dan cepat, sehingga masyarakat mulai memahami dan menyadari betapa pentingnya pendidikan anak sejak usia dini.

Anak usia dini adalah anak yang baru dilahirkan sampai usia 6 tahun. Usia ini merupakan usia yang sangat menentukan dalam pembentukan karakter dan kepribadian anak. Pada masa ini anak usia dini mengalami pertumbuhan dan perkembangannya yang sangat pesat. Menurut wiyani bahwa usia dini merupkan periode awal yang paling penting dan mendasar dalam menapaki kehidupan yang selanjutnya. Pada masa ini ditandai oleh berbagai periode penting yang fundamen dalam kehidupan anak selanjutnya sampai periode akhir perkembangnnya[1]. Sejak lahir hingga usia 2 tahun sel-sel pada bayi yang belum matang dan jaringan urat saraf yang masih lemah terus tumbuh dengan cepat dan dramatis mencapai kematangan seiring dengan pertumbuhan fisiknya. Sekitar 50\% kapasitas kecerdasan manusia telah terjadi ketika usia 4 tahun, $80 \%$ telah terjadi ketika usia 8 tahun, dan mencapai titik kulminasi 100\% ketika anak berusia 8 sampai 18 tahun. Pertumbuhan fungsional sel-sel otak tersebut membutuhkan berbagai situasi pendidikan yang mendukung, baik dalam situasi pendidikan keluarga, masyarakat, maupun sekolah[2].

Dunia anak merupakan dunia yang sangat menyenangkan dan penuh kegembiraan, seorang anak yang dididik dengan cara yang menyenangkan tanpa tekanan maka akan tumbuh menjadi pribadi yang sehat, cerdas, ceria, kreatif dan mandiri. Hal ini tentu menjadi cita-cita dan tujuan semua orang tua serta pendidik di sekolah. Salah satu tugas perkembangan anak usia dini adalah aspek kemandirian. Pada anak, istilah kemandirian umumnya dikaitkan dengan kemampuan untuk melakukan segala sesuatu sendiri, seperti memakai baju sendiri, mengikatkan tali sepatunya sendiri tanpa harus bergantung kepada orang lain. Kemandirian anak adalah kecenderungan anak untuk melakukan sesuatu yang diinginkannya tanpa minta tolong kepada orang lain[3].

Tetapi masih banyak orang tua yang belum paham tentang bagaimana cara mendidik anak dengan baik dan benar. Beberapa dari mereka bahkan masih banyak yang menafsirkan bahwa mencurahkan kasih sayang kepada anak adalah dengan cara memberikan dan menuruti semua kemauan anak. lebih dari itu bahkan ada orang tua yang selalu melayani semua keperluan anaknya. Alhasil anak tersebut akan tumbuh 
menjadi pribadi yang manja, tidak mandiri dan sulit beradaptasi dengan lingkungan baru serta selalu bergantung kepada orang lain.

Menurut Tjut Rifameutia dalam Riana penyebab anak menjadi tidak mandiri yaitu pertama, adanya rasa kekhawatiran orang tua yang berlebihan kepada anak. kedua, sikap orang tua yang tidak sabaran, daripada menunggu anak berusaha memakai sepatunya sendiri, orang tua cenderung lekas membantu agar cepat selesai. Akibatnya, anak tidak memperoleh kesempatan untuk mencoba[4]. Sejalan dengan pernyataan Robert A. Heinlein yang menyatakan bahwa "jangan melumpuhkan hidup anak dengan membuat hidupnya sedemikian mudah"[5].

Proses menuju kemandirian memang membutuhkan tahapan dan waktu yang tidak sebentar. Oleh karena itu sifat ini harus ditanamkan dan dibiasakan sejak dini, karena kemandiraian membutuhkan daya juang, tidak mudah mengeluh, harus sabar serta tidak selalu bergantung kepada orang lain. Sikap inilah yang membangun kecerdasan anak dalam menghadapi tantangan hidupnya baik saat sedang dijalani ataupun dimasa yang akan dating.

Dengan ditanamkannya kemandirian sejak dini, maka ketika dewasa anak akan lebih mudah dalam mengambil keputusan, bertanggung jawab, tidak mudah bergantung kepada orang lain dan mampu menyesuaikan diri dengan lingkungnnya[6]. Kemandirian merupakan salah satu aspek yang harus dimiliki oleh setiap anak, karena dapat mempengaruhi aktivitasnya juga berfungsi untuk membantu mencapai tujuan hidupnya[7]. Allah SWT. Berfirman dalam Q.S. Al-Mukminun ayat 62 yang menjelaskan tentang kemandirian Artinya : "Dan kami tidak membebani seseorang melainkan menurut kesanggupannya, dan pada hari ada suatu catatan yang menuturkan dengan sebenarnya, dan mereka tidak didzolomi (dirugikan)".

Dari ayat diatas dapat diambil kesimpulan bahwasanya setiap individu (peserta didik) tidak akan dibebani sebuah tugas atau beban diluar batas kemampuannya tetapi Allah Maha tahu dengan memberi beban dengan batas kemampuan individu itu sendiri. Oleh karena itu setiap individu dituntut untuk mandiri dalam menyelesaikan persoalan dan pekerjaaannya tanpa banyak tergantung pada orang lain.

Berdasarkan hasil observasi di kelompok B Kober Alhuda Alalkasbi Cipacing Sumedang, dari 20 orang siswa penulis mendapatkan sebanyak 14 siswa terbukti bahwa kemandirian mereka tergolong rendah. Penulis menggunakan instrument observasi yang terdiri dari pertanyaan-pertanyaan sesuai dengan indikator kemandirian anak usia 5-6 tahun. Diantaranya anak belum memiliki sikap percaya diri sehingga belum berani untuk tampil di depan umum dan belum mampu memakai baju sendiri. Adapun untuk kasus lain masih ada anak yang diantar oleh orang tuanya untuk masuk ke kelas, bahkan untuk pemilihan tempat duduk pun masih mengandalkan orang tua. Selanjutnya masih ada anak yang menangis ketika orang tuanya yang sedang menunggu di luar kelas tidak ada dan untuk perihal memakai sepatu masih ada anak yang masih mengandalkan orang tuanya. Maka dari itu perlu adanya cara atau metode yang dianggap tepat dan cocok dalam mengembangkan kemandirian pada anak salah satunya dengan menggunakan metode storytelling melalui musik instrumental. 
Berdasarkan permasalahan tersebut diperlukan intervensi yang dapat meningkatkan kemandirian pada anak. Kegiatan yang akan dilakukan adalah dengan metode storytelling. Metode storytelling (bercerita) merupakan kegiatan yang dilakukan oleh seseorang secara lisan kepada orang lain dengan alat atau tanpa alat tentang apa yang harus disampaikan dalam bentuk pesan, informasi atau hanya sebuah dongeng untuk didengarkan dengan rasa menyenangkan. Oleh karena itu orang yang menyajikan cerita tersebut harus menyampaikannya dengan menarik. Bercerita bukan hanya berbagi tentang isi cerita dan pengalaman tetapi juga memberikan suatu nasihat kepada anak. Selain itu bercerita juga dapat memperkenalkan anak kepada nilai-nilai moral dan sosial[8].

Ada beberapa alasan mengapa storytelling dianggap efektif dalam memberikan pendidikan kepada anak. pertama, cerita pada umumnya lebih berkesan daripada nasehat, sehingga pada umunya cerita terekam jauh lebih kuat dalam memori manusia khususnya memori anak usia dini yang masih tajam dan kuat ingatannya. Kedua , melalui storytelling anak belajar mengambil hikmah dari alur cerita yang disimak. Penggunaan metode storytelling akan membuat anak lebih nyaman dan senang tanpa beban. Peran metode storytelling bagi anak usia dini mampu menumbuhkembangkan potensi-potensi yang dimiliki oleh anak. baik dari aspek psikomotor, kognitif, afeksi maupun moral anak[9].

Dalam pelaksanaannya penulis akan melakukan metode storytelling melalui musik instrumental. Secara umum mendengarkan musik memberi pengaruh yang positif bagi otak manusia, karena musik menimbulkan vibrasi yang dapat merangsang gendang pendengaran lalu di transmisikan susunan saraf pusat disentral otak yang merupakan gudangnya ingatan. Mendengarkan musik instrumental itu sangat bermanfaat, diantaranya manfaat yang sangat populer yaitu membuat pendengaran menjadi relaks[10]. Hal ini sesuai dengan penelitian yang dilansir The Asian Parent Singapore Carol Loy, Direktur Kiderland, sekolah musik di Singapura menjelaskan bahwa musik instrumental yang dimainkan selama waktu tidur membantu anak-anak untuk tenang. Bahkan jika mereka tidak benar-benar mengantuk pada saat itu, mereka tetap berbaring dan mendengarkan musik yang sedang diputar[11]. Dari pernyataan tersebut penulis akan mencoba mengkombinasikan metode storytelling melalui musik instrumental dalam melakukan penanaman nilai-nilai kemandirian karena pada umumnya ketika anak sedang mendengarkan cerita dengan pembawaan yang asyik dan menarik mereka akan fokus juga daya pikir dan daya imajinasinya berkembang, selain itu mendengarkan cerita melalui musik instrumental membuat jiwa anak tenang tanpa beban, sehingga isi cerita serta makna yang terkandung dapat diresapi dan ditangkap oleh anak

\section{METODE}

Pendekatan penelitian ini menggunakan penelitian mix method yaitu gabungan antara pendekatan kualitatif dan kuantitatif. Penelitian kualitatif merupakan pendekatan penelitian tanpa menggunakan angka statistik tetapi dengan pemaparan secara deskriptif yaitu berusaha mendeskripsikan suatu gejala, peristiwa, kejadian yang terjadi di saat sekarang, dimana penelitian ini memotret peristiwa dan kejadian yang 
terjadi menjadi fokus perhatiannya untuk kemudian dijabarkan sebagaimana adanya. Sedangakan penelitian kuantitatif adalah pendekatan penelitian yang dapat diukur atau dihitung secara langsung yang berupa informasi atau penjelasan yang dinyatakan dalam bilanagan atau berbentuk angka[12].

Metode yang digunakan dalam penelitian ini adalah metode penelitian tindakan kelas atau Action Research. Menurut Suyanto metode action research merupakan bentuk penelitian yang bersifat reflektif dengan melakukan tindakan tindakan tertentu untuk memperbaiki atau meningkatkan praktik atau proses pembelajaran di kelas secara lebih professional[13]. Penulis menggunakan model penelitian dari Kemmis dan McTaggart dalam sukardi, secara garis besar dalam penelitian tindakan kelas model Kemmis dan McTaggart terdapat empat komponen penting yang selalu ada pada setiap siklus yaitu planning (perencanaan), acting (tindakan), observing (observasi) dan reflecting (refleksi)[14]. Penelitian ini dilaksanakan di Kelompok B Kober Al-Huda Alal Kasbi yang berlokasi di Dusun Cipacing RT 17 RW 04 Desa Mekarbakti Kecamatan Pamulihan Kabupaten Sumedang Sumedang. Penelitian ini dilakukan pada asiswa Kelompok B yang terdiri dari 13 orang. Teknik pengumpulan data dilakukan dengan metode observasi, wawancara, dokumentasi dan unjuk kerja. Teknik analisis data yang digunakan adalah teknik analisis data kualitatif dengan model Kemmis dan Tagart dan analisis data kuantitatif

\section{HASIL DAN PEMBAHASAN}

\section{Kemandirian Anak Sebelum Diterapkan Metode Storytelling Melalui Musik Instrumental Di Kober Al Huda Alal Kasbi Cipacing}

Berdasarkan analisis data hasil kemandirian anak sebelum menggunakan metode storytelling melalui musik instrumental diperoleh nilai rata-rata sebesar 51,34 dengan kategori kurang. Hal ini menunjukkan bahwa tingkat kemandirian anak masih terbilang rendah dan perlu ditingkatkan. Ada beberapa alasan yang menjadi penyebab rendahnya tingkat kemandirian anak. diantaranya dari faktor pengasuhan orang tua dan proses pembelajaran dan pembiasaan di sekolah.

Pola asuh orang tua yang terlalu memanjakan anak cenderung membentuk anak yang tidak mandiri. Proses pembelajaran dan pembiasaan di sekolah dalam upaya menumbuhkan sikap kemandirian belum optimal sebab metode yang digunakan masih klasik yaitu dengan menjelaskan secara langsung kepada anak, sehingga anak merasa bosan dan imajinasinya kurang terasah. Guru juga tidak menggunakan media yang dapat menarik perhatian anak hal ini mengakibatkan fokus dan perhatian anak sangat mudah sekali buyar

Berdasarkan analisis yang dilakukan dalam upaya meningkatkan kemandirian anak di Kelompok B Kober Alhuda Alal Kasbi Cipacing perlu adanya metode yang efektif dan media yang menarik agar kemandirian anak meningkat. Hasil penelitian lain juga menyimpulkan bahwa secara umum kemandirian anak usia 5-6 tahun di TK Pertiwi Provinsi Riau berada dalam kategori mulai berkembang[15]. 


\section{Penerapan metode storytelling melalui musik instrumental untuk meningkatkan kemandirian anak di kelompok B Kober alahuda alal kasbi cipacing}

a. Aktivitas guru dan anak pada siklus I

Berdasarkan tabel 4.6 menunjukkan bahwa aktivitas guru selama pembelajaran menggunakan metode storytelling melalui musik instrumental pada siklus I termasuk kedalam kriteria baik dengan perolehan nilai rata-rata sebesar 80,55\% sebagaimana rincian nilai yang dicapai pada tindakan petama sebesar77,77\% dan pada tindakan kedua sebesar 83,33\%. Sedangkan aktivitas anak pada siklus I termasuk kedalam kategori baik dengan perolehan nilai rata-rata sebesar 68,8\% sebagaimana rincian nilai yang dicapai pada tindakan pertama sebesar 65,38\% dan pada tindakan kedua sebesar $72,22 \%$.

b. Aktivitas guru dan anak pada siklus II

Berdasarkan 4.16 Menunjukkan bahwa aktivitas guru selama pembelajaran menggunakan metode storytelling melalui musik instrumental pada siklus II termasuk kedalam kriteria sangat baik dengan perolehan nilai rata-rata sebesar 94,44\% sebagaimana rincian nilai yang dicapai pada tindakan petama sebesar 88,88\% dan pada tindakan kedua sebesar $100 \%$. Sedangkan aktivitas anak pada siklus II termasuk kedalam kategori baik dengan perolehan nilai rata-rata sebesar 79,69\% sebagaimana rincian nilai yang dicapai pada tindakan pertama sebesar $77,77 \%$ dan pada tindakan kedua sebesar 81,61\%.

Berdasarkan hasil observasi dan analisis dalam proses pembelajaran, diketahui bahwa pada setiap siklusnya aktivitas guru dan anak mengalami peningkatan yang cukup baik. Hal ini membuktikan bahwa kegiatan metode storytelling melalui musik instrumental cukup efektif dalam meningkatkan kemandirian pada anak. Aktivitas yang dilakukan di Kober Alhuda Alal kasbi Cipacing dalam prose pembelajaran melalui 4 tahapan kegiatan, diantaranya kegiatan pembukaan, kegiatan inti, istirahat dan kegiatan penutup. Menurut Kusumastuti bahwa storytelling sebagai suatu cara pemberian pengetahuan tentang pentingnya konsumsi sayur kepada anak melalui bercerita, hal ini bertujuan untuk mengasah imajinasi dan memberi pemahaman kepada anak melalui belajar berdasarkan pengalaman-pengalaman sang tokoh dalam dongeng kepada anak, karena teknik bercerita merupakan cara yang unik untuk memberikan pendidikan kesehatan kepada anak[16].

3. Kemandirian anak di kelompok B Alhuda alal kasbi cipacing setelah diterapkan metode storytelling melalui musik instrumental

a. Kemandirian anak pada siklus I

Berdasarkan hasil perhitungan penilaian unjuk kerja pada siklus I tindakan pertama memperoleh nilai rata-rata sebesar 54,23 dengan kategori kurang. Adapun banyaknya anak yang memiliki kemampuan kemandirian dengan kriteria penilaian dapat dilihat pada tabel 4.21 Berikut ini : 
Tabel 1.

Rekapitulasi Hasil Unjuk Kerja Kemandirian Pada Siklus I

\begin{tabular}{ccc}
\hline $\begin{array}{c}\text { Ukuran tingkat } \\
\text { kemandirian anak }\end{array}$ & Jumlah siswa & Kriteria penilaian \\
\hline $80-100$ & - & Sangat Baik \\
\hline $70-79$ & - & Baik \\
\hline $60-69$ & 4 & Cukup \\
\hline $50-59$ & 6 & Kurang \\
\hline $0-49$ & 3 & Kurang sekali \\
\hline Jumlah & 13 & \\
\hline
\end{tabular}

Pada siklus I tindakan pertama terdapat indikator dalam penilaian unjuk kerja kemandirian anak yaitu, mandiri secara fisik, percaya diri, bertanggung jawab dan disiplin. Berdasarkan penjelasan pada tabel diatas, diperoleh nila rata-rata seluruh anak pada tindakan pertama yaitu 54,23\% dengan kriteria kurang. Guru dan observer mengamati bahwa masih ada beberapa siswa yang belum sepenuhnya memahami tentang konsep kemandirian yang disampaikan dalam kegiatan storytelling.

Berdasarkan hasil perhitungan penilaian unjuk kerja pada siklus I tindakan kedua memperoleh nilai rata-rata sebesar 57,88 dengan kategori kurang. Adapun banyaknya anak yang memiliki kemampuan kemandirian dengan kriteria penilaian dapat dilihat pada tabel 4.22 Berikut ini :

Tabel 2.

Rekapitulasi Hasil Unjuk Kerja Kemandirian Pada Siklus I Tindakan kedua

\begin{tabular}{ccc}
\hline $\begin{array}{c}\text { Ukuran tingkat } \\
\text { kemandirian anak }\end{array}$ & Jumlah siswa & Kriteria penilaian \\
\hline $80-100$ & - & Sangat Baik \\
\hline $70-79$ & - & Baik \\
\hline $60-69$ & 4 & Cukup \\
\hline $50-59$ & 9 & Kurang \\
\hline $0-49$ & - & Kurang sekali \\
\hline Jumlah & 13 & \\
\hline
\end{tabular}

Pada siklus I tindakan kedua terdapat indikator dalam penilaian unjuk kerja kemandirian anak yaitu, mandiri secara fisik, percaya diri, bertanggung jawab dan disiplin. Berdasarkan penjelasan pada tabel diatas, diperoleh nila rata-rata seluruh anak pada tindakan pertama yaitu 57,88\% dengan kriteria kurang. Guru dan observer mengamati bahwa nilai rata-rata pada tindakan kedua mengalami peningkatan jika dibandingkan dengan tindakan pertama. Walaupun kriteria dari perhitungan rata-rata tersebut belum mencapai target yang diharapkan. Oleh sebab itu guru dan observer merencanakan kembali untuk melaksanakan siklus II

b. Kemandirian anak pada siklus II 
Berdasarkan hasil perhitungan penilaian unjuk kerja pada siklus II tindakan pertama memperoleh nilai rata-rata sebesar 70,96 dengan kategori Baik. Adapun banyaknya anak yang memiliki kemampuan kemandirian dengan kriteria penilaian dapat dilihat pada tabel 4.23 Berikut ini :

Tabel 3.

Rekapitulasi Hasil Unjuk Kerja Kemandirian Pada Siklus I Tindakan Pertama

\begin{tabular}{ccc}
\hline $\begin{array}{c}\text { Ukuran tingkat } \\
\text { kemandirian anak }\end{array}$ & Jumlah siswa & Kriteria penilaian \\
\hline $80-100$ & 1 & Sangat Baik \\
\hline $70-79$ & 8 & Baik \\
\hline $60-69$ & 4 & Cukup \\
\hline $50-59$ & - & Kurang \\
\hline $0-49$ & - & Kurang sekali \\
\hline Jumlah & 13 & \\
\hline
\end{tabular}

Pada siklus II tindakan pertama terdapat indikator dalam penilaian unjuk kerja kemandirian anak yaitu, mandiri secara fisik, percaya diri, bertanggung jawab dan disiplin. Berdasarkan penjelasan pada tabel diatas, diperoleh nila rata-rata seluruh anak pada tindakan pertama yaitu 70,96\% dengan kriteria baik. Adanya peningkatan kemandirian pada anak, karena guru melakukan perbaikan dari kekurangan yang terjadi sebelumnya. Upaya yang dilakukan di kemas semenarik mungkin melalui media yang menyenangkan bagi anak untuk meningkatkan kemandirian yang lebih maksimal.

Berdasarkan hasil perhitungan penilaian unjuk kerja pada siklus II tindakan kedua memperoleh nilai rata-rata sebesar 86,53 dengan kategori sangat baik. Adapun banyaknya anak yang memiliki kemampuan kemandirian dengan kriteria penilaian dapat dilihat pada tabel 4.24 Berikut ini :

Tabel 4.

Rekapitulasi Hasil Unjuk Kerja Kemandirian Pada Siklus I Tindakan kedua Ukuran tingkat Jumlah siswa Kriteria penilaian kemandirian anak

\begin{tabular}{ccc}
\hline $80-100$ & 12 & Sangat Baik \\
\hline $70-79$ & 1 & Baik \\
\hline $60-69$ & - & Cukup \\
\hline $50-59$ & - & Kurang \\
\hline $0-49$ & - & Kurang sekali \\
\hline Jumlah & 13 &
\end{tabular}

Pada siklus II tindakan kedua terdapat indikator dalam penilaian unjuk kerja kemandirian anak yaitu, mandiri secara fisik, percaya diri, bertanggung jawab dan disiplin. Berdasarkan penjelasan pada tabel diatas, diperoleh nila rata-rata seluruh anak pada tindakan pertama yaitu $86,53 \% \%$ dengan kriteria sangat baik. Guru dan observer mengamati bahwa nilai rata-rata pada tindakan kedua mengalami peningkatan. 


\section{KESIMPULAN}

Kemandirian anak di kelompok B Kober Alhuda Alal Kasbi Cipacing sebelum diterapakan metode storytelling melalui musik instrumental masih rendah. Hal ini dibuktikan dari kemampuna kemandirian anak dengan kriteria kurang. Kegiatan metode storytelling melalui musik instrumental untuk meningkatkan kemandirian anak dilihat dari aktivitas guru dan anak pada siklus I dan II mengalami peningkatan. Pada siklus I dengan kriteria baik dan pada siklus II dengan kriteria sangat baik. Aktivitas anak pada siklus I dan siklus II dengan kriteria baik. Kemampuan kemandirian anak di kelompok B Kober Alhuda Alal Kasbi Cipacing setealah diterapkan metode storytelling melalui musik instrumental mengalami peningkatan dari siklus I ke siklus II. Pada siklus I dengan kriteria kurang. Dan pada siklus II nilai rata-rata yang diperoleh meningkat menjadi dengan kriteria sangat baik. Berdasarkan hasil yang diperoleh, maka terbukti bahwa metode storytelling melalui musik instrumental dapat meningkatkan kemandirian anak.

\section{PENGHARGAAN}

Terima kasih penulis ucapkan kepada kepala sekolah dan guru di kelompok B Kober Alhuda Alal Kasbi Cipacing terlibat dan membantu terlaksananya penelitian ini. Tidak lupa diucapan terima kasih kepada editor dan reviewer Jurnal Murhum yang sudah memberikan kesempatan sehingga jurnal bisa untuk dipublish/diterbitkan.

\section{REFERENSI}

[1] N. Nurdin, J. Jahada, and L. Anhusadar, "Membentuk Karakter melalui Kegiatan Ekstrakurikuler Pramuka pada Anak Usia 6-8 Tahun," J. Obs. J. Pendidik. Anak Usia Dini, vol. 6, no. 2, pp. 952-959, Jul. 2021, doi: 10.31004/obsesi.v6i2.1603.

[2] N. A. Wiyani, Pendidikan Karakter Berbasis Iman dan Taqwa. Teras, 2012.

[3] Z. Arifin, "Menelusuri Tokoh Zakiah Daradjat Sebagai Pemikir Pendidikan dan Perawatan Mental," J. Pendidik. Islam Rabbani, vol. 2, no. 2, 2018.

[4] D. Utami, "Upaya peningkatan kemandirian anak melalui metode bercerita," J. Pendidik. Luar Sekol., vol. 13, no. 1, p. 1, May 2019, doi: 10.32832/jpls.v13i1.2774.

[5] R. E. Parebong, "Pendekatan Trauma Healing Untuk Mengatasi Pathological Grief Pada Anak Usia Remaja Yang Ditinggal Mati Orang Tuanya," Ra'ah J. Pastor. Couns., vol. 1, no. 2, pp. 109-120, 2021.

[6] N. Safitri, S. Setiawati, and W. Aini, "Gambaran Penanaman Kemandirian pada Anak Usia Dini oleh Orang Tua dalam Keluarga," SPEKTRUM J. Pendidik. Luar Sekol., vol. 6, no. 1, p. 84, Mar. 2018, doi: 10.24036/spektrumpls.v1i1.9005.

[7] L. Hewi, "KEMANDIRIAN USIA DINI DI SUKU BAJO (Studi Kasus pada Anak Usia 46 Tahun di KB Nur' Ain Mola Selatan Kabupaten Wakatobi Provinsi Sulawesi Tenggara tahun 2015)," JPUD - J. Pendidik. Usia Dini UNJ, vol. 9, no. 1, pp. 75-92, 2015, doi: 10.21009/JPUD.091.05.

[8] R. Sabil, "Bermain, Bercerita, dan Menyanyi Bagi Anak Usia Dini," Jakarta PT. Luxima Metro Media, 2014.

[9] D. Imawati, "Pengaruh Storytelling Terhadap Kemandirian Anak Pra Sekolah," Motiv. J. Psikol., vol. 2, no. 1, pp. 37-42, 2019, doi: 10.31293/mv.v2i1.4284.

[10] L. S. Puspitasari, "Pengaruh Musik Instrumental terhadap Kenyamanan Membaca di Badan Perpustakaan dan Arsip Daerah Provinsi Sulawesi Selatan," Universitas 
Islam Negeri Alauddin Makassar, 2017.

[11] B. Lucy, P. Si, C. Ht, A. J. Rizky, B. L. I. Edu, and others, Dahsyatnya Brain Smart Teaching: Cara Super Jitu Optimalkan Kecerdasan Otak dan Prestasi Belajar Anak. Penebar PLUS+, 2012.

[12] Sugiyono, Metode Penelitian Pendidikan: Pendidikan Kuantitatif, Kualitataif dan $R \& D$. Bandung: Alfabeta, 2016.

[13] R. Wahyuni and Erdiyanti, "Meningkatkan Kemampuan Motorik Halus Anak Melalui Finger Painting Menggunakan Tepung Singkong," Murhum J. Pendidik. Anak Usia Dini, vol. 1, no. 1, pp. 28-40, Jul. 2020, doi: 10.37985/murhum.v1i1.5.

[14] S. Suriati, S. Kuraedah, E. Erdiyanti, and L. O. Anhusadar, "Meningkatkan Keterampilan Motorik Halus Anak melalui Mencetak dengan Pelepah Pisang," J. Obs. J. Pendidik. Anak Usia Dini, vol. 4, no. 1, p. 211, 2019, doi: 10.31004/obsesi.v4i1.299.

[15] Daviq Chairilsyah, "Analisis Kemandirian Anak Usia Dini," PAUD Lect. J. Pendidik. Anak Usia Dini, vol. 3, no. 01, pp. 88-98, Oct. 2019, doi: 10.31849/paudlectura.v3i01.3351.

[16] A. Suryandi, T. Hariyanto, and W. D. Metrikayanto, "Perbedaan Konsumsi Sayur Sebelum Dan Sesudah Pendidikan Kesehatan Dengan Metode Storytelling Pada Anak Sekolah Dasar Di Sdn Mulyoagung 04 Dau Malang," Nurs. News (Meriden)., vol. 3, no. 1, pp. 237-246, 2018. 